\title{
STEPPING INTO A NEW WORLD: THE MEANING OF BECOMING ILL FOR THE CHILD WITH CANCER ${ }^{1}$
}

\author{
Malueska Luacche Xavier Ferreira de Sousa², Altamira Pereira da Silva Reichert ${ }^{3}$, Lenilde Duarte de Sá4, \\ Filomena Elaine Paiva Assolini ${ }^{5}$, Neusa Collet ${ }^{6}$
}

${ }^{1}$ Article extracted from the dissertation Significados do viver com câncer para a criança, developed in the Nursing Graduate Program of the Center of Health Sciences (CCS) of the Federal University of Paraíba (UFPB), 2013.

${ }^{2}$ M.Sc. in Nursing. Substitute Professor of the Maternal-Infant Department of the State University of Paraíba. Paraíba, Brazil. E-mail: malu_luacche@hotmail.com

${ }^{3}$ Ph.D. in Nursing. Professor of the Nursing Graduate Program of the CCS/UFPB and the Department of Public Health and Psychiatric Nursing (DESPP) of UFPB. Paraíba, Brazil. E-mail: altareichert@gmail.com

${ }^{4}$ Ph.D. in Nursing. Professor of the Nursing Graduate Program of the CCS/UFPB and the DESPP/UFPB. Paraíba, Brazil. E-mail: lenilde_sa@yahoo.com.br

${ }^{5}$ Ph.D. in Psychology. Professor of the Faculty of Philosophy, Sciences and Languages of Ribeirão Preto, University of São Paulo. São Paulo, Brazil. E-mail: elainesol@netsite.com.br

${ }^{6}$ Ph.D. in Nursing. Professor of the Nursing Graduate Program of the CCS/UFPB and the DESPP/UFPB. Paraíba, Brazil. E-mail: neucollet@gmail.com

\begin{abstract}
This is a qualitative study with the aim to understand the meaning of experiencing illness for a child with cancer. The thematic drawing-story was used, with eight children aged between 6 and 12 years old, from February to May of 2012. The material was analyzed according to the theoretical and analytical framework of the French Discourse Analysis line, which seeks to understand the socio-historical processes of meaning production. The study revealed that, for the child with cancer, the disease is found out in an unexpected manner and he/she is soon inserted into a new context. In addition, the child faces barriers that may delay diagnosis, having his/her routine changed. The child presents signals and symptoms that cause discomfort and anxiety. At the same time, the child hopes to be healed with the treatment accomplishment. The results may contribute to changes in nursing care for this population. KEYWORDS: Child. Oncologic nursing. Pediatrics.
\end{abstract}

\section{ADENTRANDO EM UM NOVO MUNDO: SIGNIFICADO DO ADOECER PARA A CRIANÇA COM CÂNCER}

RESUMO: Pesquisa qualitativa, que objetivou compreender o significado de experienciar o adoecimento para a criança com câncer. Utilizou-se o desenho-estória com tema, com oito crianças entre 6-12 anos de idade, de fevereiro a maio/2012. Procedeu-se à análise do material conforme o referencial teórico-analítico da análise de discurso francesa, que pretende compreender os processos sóciohistóricos de produção de sentidos. O estudo apreendeu que, para a criança com câncer, a doença é descoberta de modo repentino e logo é inserida em um contexto novo. Depara-se com barreiras que podem retardar o diagnóstico, e tem sua rotina alterada. A criança apresenta sinais e sintomas que geram desconforto e ansiedade. Ao mesmo tempo, tem esperança de cura com a realização do tratamento. Os resultados poderão contribuir para mudança no cuidado de enfermagem a essa população.

PALAVRAS CHAVE: Criança. Enfermagem oncológica. Pediatria.

\section{ENTRANDO EN UN NUEVO MUNDO: EL SIGNIFICADO DE ENFERMAR PARA EL NIÑO CON CANCER}

\begin{abstract}
RESUMEN: Investigación cualitativa, que tuvo como objetivo comprender el significado de la experiencia de la enfermedad para los niños con cáncer. Se utilizó el dibujo-historia temático, con ocho niños de 6-12 años de edad, de febrero a mayo/2012. Se procedió a analizar el material conforme el marco teórico y analítico del análisis del discurso francés, cuyo objetivo es comprender los procesos socio-históricos de la producción de significado. El estudio ha entendido que para el niño con cáncer, la enfermedad es descubierta de modo repentino y prontamente es fijada en un nuevo contexto. Se encuentra con algunos obstáculos que pueden retrasar el diagnóstico y cambiar su rutina. El niño presenta señales y síntomas que causan malestar y ansiedad. Al mismo tiempo, hay la esperanza de cura con la finalización del tratamiento. Los resultados pueden contribuir a los cambios en la atención de enfermería para esta población.
\end{abstract}

PALABRAS CLAVE: Niño. Enfermería oncológica. Pediatría 


\section{INTRODUCTION}

The growing incidence and the countless repercussions in the lives of children and families experiencing cancer are among the major characteristics of this disease. The diagnosis brings about relevant changes in the child's lifestyle, provoking physical and emotional alterations resulting from the lack of comfort, pain, disfigurement, dependence, and loss of self-esteem. ${ }^{1}$ An attentive look at altered social aspects is quite a significant action in the oncologic treatment, as the child needs to receive comprehensive care. The cure should not be only based upon the biological recovery, but also on the child's well-being and quality of life. In this sense, the child and his/her family need to be provided with all necessary psychosocial support, beginning in the diagnosis and going through the stages of the treatment. Such support demands the commitment of a multiprofessional health team and a close relationship among the different sectors of society involved in the health care support of the child and his/her family. ${ }^{2}$

Psychosocial factors embedded in the healthdisease process of children with cancer include their distancing from home, family, friends and school, as well as all the changes undergone by the child while experiencing the illness. ${ }^{3}$ The sickening process unleashes a lack of balance in their existence, when the subject is no longer an active agent, but a passive one concerning the aspects of his/her life. Hence, the emotional conditions are crucial toward recovering the person's health status, both in the diagnosis and hospitalization processes, as well as in the way the disease is sedimented in his imagination. ${ }^{4}$

From the time cancer is diagnosed onwards, a pathway opens up toward uncertain, painful, prolonged treatments that modify the body, shock the family, and often keep friends away, thus weakening the person's future plans and bringing about an imminent possibility of death. ${ }^{5}$ In this perspective, the child experiences a scary, striking disease, and has to get used to unknown, distressing health services.

One of the major and singular psychosocial aspects unleashed in a child with cancer is the meaning of the sickening process or, in other words, the senses that are built from the moment he/she finds out the illness. Nevertheless, this aspect is generally expressed by the voice of family members and health professionals who cope with the situation, and the viewpoint of the child experiencing the disease is rarely captured.
The apprehension of the child's voice by scientific studies and his/her multiple languages is a very important step and concurrently a challenging action. One study ${ }^{6}$ points out that the research with children is particularly necessary and justifiable to the production of specific knowledge or to other sorts of benefits to this population group, presenting results that would not be achieved without their direct involvement. Whenever children are given a voice, we are provided with the opportunity of understanding the dimension of the disease in their lives, a process that is singularly experienced by them, a personalized knowledge. ${ }^{7}$ Therefore, it is believed that the attention to the way the child with cancer addresses the sickening process can provide the necessary support for an effectively comprehensive and humanized nursing practice.

There are few studies in which the child is recognized as a subject that finds out the cancer experience. It should be highlighted that any investigation on this issue may become a fundamental step toward understanding this unusual moment, thus enabling a different look at the alterations of the child's daily life and the adaptations he/she has to deal with. As such, a question should be posed: how is it for the child to discover the disease? In order to answer this question, the present study had the aim to comprehend the meaning of the sickening experience for the child with cancer.

The knowledge approached from the standpoint of the child on his/her cancer experience is expected to contribute to the reflections on the work of the nurse while planning health care actions toward the child and his/her family, respecting their individualities and specificities and meeting the real needs of people in similar conditions.

\section{METHODOLOGY}

This qualitative study was carried out in a Support Center for Children with Cancer in the state of Paraíba. The center assists children and teenagers from 0 through 18 years of age, as well as their caregivers, who usually come from the countryside of the state and from neighboring states. Due to their financial difficulties, these families are solely dependent on this place to carry out the child's treatment process. The center was inaugurated in 1997 and is capable of assisting up to 24 children and adolescents with their respective companions. 
Eight children with cancer participated in the research. Their selection took into account the following criteria: being between six and twelve years of age; having physical and emotional conditions to participate in the study; and having a confirmed diagnosis of cancer for over six months.

In order to assess the physical conditions of the participating children, the study employed the Performance Status (PS) scale of the Eastern Cooperative Oncology Group (ECOG), which establishes scores ranging from 0 (zero) through 4 (four) (PS 0 and PS 4), being 0 (zero) the patient with normal activity and 4 (four) the patient restricted to bed. ${ }^{8}$ Hence, the exclusion criteria adopted in the selection of participants were as follows: children with PS 3 and PS 4 scores, that is, more dependent patients; and visually handicapped children who were not able to draw, an essential criterion employed by the thematic drawing-story technique.

Data were collected between February and May of 2012 by the application of the thematic drawing-story technique. ${ }^{9}$ In this study, the theme employed was "a child with cancer". The subject was instructed to freely produce drawings that would serve as a stimulus for a story-telling process immediately after the production of the drawing. Following the conclusion of this phase, the subject was required to provide follow-up clarifications (the "inquiry" phase). Finally, he/ she was asked to title the story. ${ }^{10}$ It is important to highlight that only told stories were assessed in this research. The drawing was used as a triggering factor of the dialogue with the child, and it was employed by this study as an illustration of the child's experience.

The following procedure was carried out after the establishment of the contact with the children and the permission of those who were responsible for them: the child was invited to head to a reserved space and to sit down at a table facing the researcher. Right after the interaction process took place, he/she received twelve color pencils and one black pencil, together with a sheet of paper. The child was then asked to freely draw. After finishing the drawing, the child was required to tell a story about what he/she had drawn. In the inquiry phase, questions were made in order for the child to provide clarifications on either the drawing or the told story, aiming to deepen addressed contents. In the end, the child was requested to title the story. In a second phase, the researcher inserted the following theme: "draw a child with cancer". After finishing this second task, the child was asked to tell a story on this drawing. The inquiry phase took place again and the child was finally required to provide a title to the story he/she had created. The stories were all recorded and transcribed for further analysis.

The assessment of empirical materials was carried out in compliance with the theoretical-analytical background of the French discourse analysis line. The study began at the linguistic surface representation level and evolved to the discourse level, thus building the discourse corpus, meaning the core of the discourses expressed by the children, in which signification mechanisms can be observed. The discourse object was built after the first round of analysis. The corpus was read again and again, constituting a constant to-and-fro process between theory and analysis, aiming to comprehend meaning production. The analytical reading of the discourse object pointed out several hints of the analytical devices employed in the subjects' discourses. ${ }^{11}$ By identifying paraphrastic, polysemic and metaphoric processes, the arrangements of the discourses were correlated following the analysis of the statements that characterized the subjects' discourses expressing their ideological standpoint, their correlation with other discourses, historical affiliation networks, and interdiscourses.

All legal and ethical aspects required for studies with human beings were observed. The research was approved by the Research Ethics Committee of the Center of Health Sciences of the Federal University of Paraíba (CEP/CCS) under protocol number 0380/2011. The adults responsible for the children participating in the study signed the Free and Informed Consent Form.

\section{RESULTS AND DISCUSSION}

The analytical device was built upon the stories told by the children, the interpretation of the researchers, the theoretical background, and the conditions that produced the distinct languages and standpoints. Two discourse groups were organized: experiences of the child during the process of discovering the cancer and the diagnostic itinerary of discovering the cancer. Based on the analysis of the French discourse analysis line, the following aspects were identified and assessed: the ideological position of subjects; the correlations among the discourses; the affiliated network of meanings; the crisscrosses of the discourse; the unsaid in the discourse; the interdiscourse; and the metaphor. 
In order to present the fragments of the discourse, the study adopted a specific codification to the subjects: Cebolinha, Cascão, Dudu, Franjinha, Aninha, Pelezinho, Mônica, and Magali (names of Brazilian comic book characters). In order to identify the adults responsible for the children, or the cities quoted by the children, the study employed letters A, B, C and D. Aiming to preserve the identity of the health institutions referred to, their names were replaced with letters $X$ and $Y$. Among the subjects of the study, there were three female and five male children. Their diagnoses were as follows: leukemia (5), lymphoma (1), kidney cancer (1), and ovarian cancer (1). As for the treatment stage, three children were undergoing chemotherapy and five were receiving monthly and half-yearly follow-ups. The lowest amount of time for the diagnosis was eight months, and the highest, six years.

\section{Experiences of the child during the process of discovering the cancer}

The subject-child with cancer involuntarily accesses a strange context and has to experience totally or partially unknown signals and symptoms that generate diverse reactions, in addition to being submitted to a number of new procedures and environments, which stir his/her daily life. The discourse arrangements make it possible to understand the perceptions of the subject-child that something is not fine in his/her health status due to the signals and symptoms displayed. As observed, the discovery of the disease stands out as a sudden blow, an abrupt occurrence in a moment when the child was experiencing his/her daily routines and activities and seemed to be apparently healthy. In this perspective, the child's sickening process is an unforeseen, undesirable event. Depending on the type and precocity of the diagnosis, the disease is able to leave severe physical and psychic after effects. ${ }^{12}$

The fragments of the children's discourses indicate that the subject-child experiencing the discovery of cancer reveals it in quite a particular way, highlighting how unexpectedly the disease took place, provoking the appearance of symptoms overnight, causing him/her to be immediately taken to health service facilities and resulting in the diagnosis of an unknown event that brings about countless stigmas. This line of events can be seen in the following pieces of discourses:

[...] a child [the child in the drawing] that got sick all of a sudden, because that's how he got sick, out of the blue. At night, then, when I discovered the disease, I was eating one day, then I overate and started vomiting, then the pains showed up, all of a sudden (Pelezinho).

[...] i was watching TV at the hammock and I said, 'mom, my neck hurts and also my arm'. Then, she saw I had the fever and early in the morning we went to the hospital. Then, they found out this thing (Cebolinha).

[...] he [the child in the drawing] has leukemia. One day, while he was playing, he fell and was taken to the doctor. Then, they examined him in order to know what that was all about, and they found out it was leukemia, a type of cancer (Cascão).

These excerpts from the subjects' discourses report on the way they realized the process of discovering cancer, either identifying themselves as subjects or indirectly projecting and mentioning a subject-other when referring to the child who produced the drawing.

The surprise at the appearance of the disease is quite clear, as shown by the words of Pelezinho, got sick all of a sudden, because that's how she got sick, out of the blue. It may be also inferred by the unsaid words in the discourse that the subjectchild considered himself to be a healthy kid with a structured life and growing in a unique way, ${ }^{13}$ up until the moment when the signal or symptom unleashed the appearance of the cancer.

The subject-children in this study correlate the symptoms with an episode they deem to have triggered the disease, although such event actually did not have the power to do so. The materiality of the discourse indicates that the disease is symbolically connected to an event, as shown by the following statements:

[...] one day, while he [the child in the drawing] was playing, he fell and was taken to the doctor, and they found out it was leukemia (Cascão).

[...] $i$ was eating one day, then I overate and started vomiting, and the pains showed up, all of a sudden (Pelezinho).

In these pieces of discourse, the subject-children replace the term cancer with metaphors, such as my disease or this thing. The latter, in a certain way, corresponds to a culturally rooted naturalized censorship, as it represents a mortal disease that has been apprehended by the children in their social interactions, leading them to replicate the same perception and ideologically reproduce the situation they were undergoing by means of using exactly the same meaning production mechanism. People with a diagnosis of cancer, or people who refer to the disease, use the expres- 
sion "that disease" as a behavior of someone who wishes to drive the disease away. The demonstrative pronoun "that" drives the disease away from the person, whereas the possessive pronoun "my" attracts and sediments the evil. Therefore, the children start substituting the term cancer with other terms, aiming to minimize or omit the danger the disease brings about whenever it is mentioned.

In our society, the stigma of the oncologic disease is related to negative feelings, frequently to the expectation of death, as a "cursed disease". Such difficulty of acceptance may be assigned to several factors, including the fear of a prolonged suffering process in the terminal phases of the cancer ${ }^{14}$ and imminent death.

The signals and symptoms originated from cancer provoke feelings and ideas that give birth to different imagery, giving rise to fantasies, and are often related to notions of "evil", "danger", "threat", and "death", aspects that can mobilize a wide array of expectations and attitudes on those who are affected by the disease, on their social environment and on society at large. ${ }^{15}$

The appearance of the disease is an abrupt occurrence, at a moment when the children perform their habitual activities, such as playing or watching $\mathrm{TV}$, as observed in the following statements:

[...] I was in the hammock, watching TV (Cebolinha).

[...] one day, when he [the child in the drawing] was playing [...] (Cascão).

[...] when he [the child in the drawing] was playing soccer (Dudu).

In addition to these activities, the discovery of the disease sometimes takes place close to special dates to the subject-child, such as his/her pre-school graduation celebration, shown by some fragments of the discourses. Hence, as it should be expected by a sudden blow, this moment evokes losses, discontinuities and ruptures:

[...] I was very little when I arrived at the hospital, I was just six years old, and I was ready for my first graduation [...] (Aninha).

The signifier was ready for is revealed in the involuntary postponement of plans and the beginning of the adaptation process to the disease for subject Aninha. In this sense, dreams and projects are torn down and will be replaced with sentiments of loss. The sickening process is globally integrated to the child's daily life, implying a continuous experience of limitations and all aspects related to this group of illnesses. ${ }^{16}$
A subject-child reports that, [The child in the drawing] lived just fine, but once he was playing soccer with a bunch of other children and he fainted, and was taken to the hospital [...] because he was very weak, because he did not eat much, he did not eat enough, I mean, because he had cancer (Dudu).

The fragment of the discourse above reveals that the child in the drawing used to have a healthy life up to the moment when a symptom destabilized his well-being, the activity of playing soccer, causing him to deal with the hospital environment and the discovery of cancer. The statement ratifies that the perception of being sick is only formulated following the exacerbation of symptoms, which evidences the symbolic power that signals and symptoms have in the discourse. Additionally, the interdiscourse - the current interpretation in the child's context that children get sick when they do not eat - may also be apprehended.

A study ${ }^{16}$ shows that children with cancer usually do not feel sick. This finding may stem from the fact that, for many children, the existence of the disease is associated with clinical manifestations and the treatment (visits to outpatient facilities, chemotherapy), as the disease is generally not present in the intervals of such episodes. Besides, the definition of "being sick" is often conditioned by the harmony existing between the patients' perception on their commitment to their own welfare and the perceptions of people around them on their health status. ${ }^{14}$

The subject-children describe the initial clinical manifestations of cancer by highlighting signals and symptoms that preceded the diagnosis. Pain, vomiting and fever are a few among them. In this process, pain is the most constant aspect, showing a strong correlation with the discourses.

I felt deep pain. I can't explain it. I don't feel it anymore. I cried and cried because I wanted it to go away (Cebolinha).

It was very bad because he thought that pain would never stop (Cascão).

[The child in the drawing] had fever, headache and tumor [...], tummy ache, headache, his tummy was swollen, [...] his leg was swollen (Franjinha).

That was my disease, I felt pain in my legs and arms, I usually had to lie down, I asked my sister to massage them and the pain stopped, but later it returned (Aninha).

These fragments in the discourses clearly show that the position of a subject-child experiencing oncologic pain is revealed as if there were no 
words to express how it was to feel it. Nevertheless, pain stands out as a persisting fact that provokes sensations of discomfort and permeates the child's physical and emotional dimensions. Such positioning reaffirms how unpleasant it is for the children to feel pain, as well as their desire for it to be a temporary condition. The statement he thought that pain would never stop (Cascão) shows the feeling of hopelessness concerning the cessation of the symptom. The experience of the oncologic pain contributes to construct a memory of meanings regarding this symptom, in which the child in the drawing takes up the position of a hopeless subject toward overcoming something that brings him/ her plenty of discomfort.

A research points out that the child's reference to the "feeling sick" process is based on his/ her sensations of not feeling well, especially on the pain as a signal that the disease is present. ${ }^{15}$ Therefore, "physical pain is one of the major concerns of the children whenever cancer is diagnosed, as cancer is globally known as a painful disease. Pain is a combination of physical, emotional and spiritual pain". 17:690 The pain experienced by the child with cancer is influenced and determined by his/her level of development, by the way he/ she expresses pain and the ability to cope with it. ${ }^{18}$

The period to accurately diagnose the disease stands out as quite a difficult phase, a time of instability that requires several practical learning processes, such as coping with pain, the environment and the hospital procedures. ${ }^{19}$ In this sense, the child and his/her caregivers should be duly oriented and provided with assistance, as well as supported by a multiprofessional team and having their bio-psycho-social needs cared for in order to help them positively deal with this phase. The discourses show that whenever any alteration in the child's health status takes place, the health care services are immediately sought. Nevertheless, the elucidation of this new context is not always as fast as it is expected, and the child and his/her family often experience an exhausting itinerary toward the discovery of the disease.

\section{Diagnostic itinerary of discovering the cancer}

After signals and symptoms show up, the child and his/her caregiver seek the health services. The fragment of the discourse early in the morning we went to the hospital. Then, they found out this thing (Cebolinha) clearly shows the relevance the child and his caregiver give to the immediate search for health services, aiming to find answers regarding what is going on. In this statement, Cebolinha takes the position of a subject who tries to understand what is wrong in his health status.

A study ${ }^{20}$ highlights that whenever parents realize that there is something wrong in the child's health status, they immediately seek medical care in the public system, such as Primary Healthcare Centers, Emergency Services or in the supplemental health system. These attitudes are important so that an early diagnosis of child cancer is achieved.

Although the appearance of the oncologic disease is a sudden fact in the perception of the subject-child, the length of time taken by the medical diagnosis is not equally perceived. The fragments of the discourses depict the delay/ uncertainty, the lack of care, the comings and goings of the child and his/her caregivers to health services, as well as the trips to different cities in search for an accurate diagnosis and the beginning of the treatment in reference centers. The following statements show these perceptions:

[...] we went to $B$, but there was no doctor there, and then they sent us to A. We got here and I was hospitalized, had the surgery and the biopsy [...] (Cebolinha).

[...] the doctor said that it was worm infection, these sorts of things. We started traveling from one place to another, up until the doctor told me to come to A. Then, we did it (Pelezinho).

The study shows that after the symptoms appeared, the subject-child and his/her family started carrying out an itinerary in search for answers for what was going on, sometimes displacing from the city they used to live to other towns, as their hometowns had neither sufficient resources for the diagnosis nor any condition to perform the treatment. Despite the fact that parents seek for health services as soon as the early signals and symptoms show up, the lack of professionals prevents the care process from taking place right away. Such occurrences may delay the diagnosis and intensify the suffering of the child in this initial phase of the disease.

The delay or the error in properly diagnosing cancer is a frequent fact, especially due to the lack of specificity in the symptoms presented. The search for help causes the child and his/her family to undergo different medical specialties, sometimes resulting in an incorrect diagnosis, which delays and hinders the assimilation of the idea of having an oncologic disease and, conse- 
quently, undermines the treatment and favors future complications. ${ }^{15}$

In the fragment of the discourse the doctor said that it was worm infection, these sorts of things. We started traveling from one place to another (Pelezinho), it can be interpreted that during the early manifestations of the disease subject Pelezinho and his family experienced real pilgrimages, moments when doubt is a persisting ally and information is not sufficient, thus filling everyone with insecurity, anguish and fear. The discourse of subject Pelezinho is crisscrossed by the statement of another subject. He embodies the information of a healthcare professional. This statement shows the position of the subject-child who expects an answer to his problem. When explanations are offered in simplistic terms, the suffering time of both the child and his/her family is expanded. Nevertheless, even facing insufficient answers, they do not give up, in spite of having to keep making trips.

Children do realize the problems they have to cope with since the onset of symptoms up until the definition of the cancer diagnosis. Among these, they quote various diagnostic hypotheses with no solution whatsoever for that health problem, the difficulties of access to performing exams and being referred to specialized services, which reflects how frail some principles of the Unified Health System (SUS), such as accessibility and comprehensiveness, still are. Nonetheless, the early definition of the diagnosis, aiming to a more accurate prognosis of the child cancer, is an indispensable step. Hence, effective actions involving the joint work of health organizations and educational institutions should be taken, so that human beings are valued and subjects are rescued in their totalities. ${ }^{20}$

The insertion of both the child and his/her family in the partially or fully unknown world of the hospital environment, with the constant need for exams and invasive procedures, contact with unknown people and devices, and incomprehensible terms are intrinsic factors in the itinerary toward diagnosing cancer. In other words, the child accesses an unpleasant universe very much distinct from that of his/her imagination.

In search for the diagnosis, the performance of exams is perceived by the subject-child as an activity that is repeated again and again, according to the following piece of discourse: they carried out an exam in D and said that it was leukemia, they carried out an exam in E and they said it was leukemia, they carried out an exam here [A] and they said it was leukemia (Aninha).
This fragment reveals the recurrence of the same event in different sites, thus reinforcing the presence of the disease, the acceptance process and the experienced pilgrimage from one place to another toward the discovery of the cancer. The repetition of the expression carried out an exam shows that the child is not conceptually aware of which exam was actually performed. On the other hand, the repetition of the fragment they said it was leukemia shows that the child was aware of the importance of the exam toward helping find out the cancer diagnosis.

This new reality found by the subject-child is described in the following discourse: we found it out back there in that place, wasn't it, C [father]? That doctor used that photography device, that massaging stuff, that hand device that makes massage, how is it called? That... [...] ultrasound, isn't it? That stuff doctors use with sort of a cream on the person's tummy? That stuff found it out! The doctor said that it was a lump, she said that we should run to A. Treatment is not good here as it is at $X$ (Pelezinho).

The network of meanings to which subject Pelezinho is affiliated is linguistically materialized by signifiers there and here. While the area where he lives is seen as the place of the discovery of the lump, yet a site that is not able to perform the adequate treatment, the $\mathrm{X}$ institution is interpreted as the place where the cure, as well as the well-being and care, are offered and guaranteed. The position of Pelezinho as a subject-child that just found out he had a serious disease shows someone who suddenly got sick and was inserted into an unknown reality with different people, devices and terms, a person that sees his one and only possibility of overcoming the disease by traveling to another city and beginning the treatment at a certain institution, as if he had abruptly been pushed into another reality.

Pelezinho's discourse is crisscrossed by the discourse sedimented in the health area, as he borrows several terms from this field. Authors ${ }^{21}$ affirm that discourses crisscrossed from other discourses are actually the constituents of the subjects' discourses. Subjects in the discourse analysis are deemed to be asubjected, that is, materially constituted by the language and duly inquired by ideology.22

The developments of the cancer diagnosis, the conception of the severity of the disease and the urgency to initiate treatment are revealed in the fragment she said that we should run to $A$. The metaphor run used by subject Pelezinho implies 
the need of searching for reference centers as quickly as possible in order to trigger the treatment process, thus showing how much the subject demanded specialized and fast care. His opaque discourse shows a child that did not have another choice but displacing to another city for treatment, as his life depended upon it.

In this sense, both the child and his caregiver will have to engage in successive trips, hoping for a future without the disease. The displacement to reference centers brings about countless uncertainties regarding where to stay during the treatment and how to provide for the family in a frequently unknown city where they have no family or friends to count on. In addition, the need to go over these itineraries demands financial investments that are not always within the reach of the social-economic reality of the family.

The subject-child with cancer perceives the disease and is immediately inserted into a new context. In the pathway toward the diagnosis, the child comes across several obstacles that are able to delay him/her. After the confirmation of the disease, the new situation brings along a severe interruption of routines and a burst of feelings of insecurity that may be quite negative in coping with the challenge. Amidst this context, the child feels signals and symptoms that generate discomfort and anxiety. Concurrently, the comings and goings to reference centers for the treatment processes give him/her hope for the cure. These meanings represent the experience of the subjectchild while coping with cancer and provide the nursing practice with unique opportunities to reflect on the specific care of this population.

\section{FINAL CONSIDERATIONS}

The sickening moment originates strong impacts in the lives of both the children and their family while experiencing child cancer. The study showed that the discovery of the disease means to go through signals and symptoms that suddenly take place. These manifestations make the child aware of the presence of the disease and may occur at any moment. Immediately after being identified, the disease leads the child to another reality that will cause him/her to experience what it means to have cancer.

The subject-child approaches the phase of discovering cancer as a continuous search for medical services aiming to an accurate diagnosis. Therefore, it is indispensable that the child health- care integrated network be qualified in order to successfully diagnose cancer in its early stages. Additionally, the sickening process brings about a sense of alteration of habits and routines, leaving the child with no other choice. His/her recovery depends upon such a change. This requires the subject to adapt to a new reality. Even facing several alterations in his/her daily life, the subjectchild realizes that, although the treatment is full of adversities, it means his/her only possibility to eliminate the disease.

Taking into account that the discovery of cancer suddenly causes the child and his/her caregivers to dive into a singular reality, the findings in this study show how they experience some aspects of the emergence of the disease, as well as how the discovery process was for the child. These findings can reinforce and broaden the sensitivity of nursing professionals in caring for these subjects as they enter the sickening process, thus benefiting the development of actions directed to the comprehensive care of this population.

Additionally, these findings can also subsidize the process of providing adequate orientation and psychosocial support at the moment the family discoveries the disease, as well as a qualified listening process and sensitive dialogue that will enable both the child and his/her family to express their demands. In this perspective, the information provided to the child must be conveyed in such a way that he/she understands what will come in the future, allowing him/her to build more appropriate meanings and fantasies toward coping with the disease. For this purpose, the child must count on an adequate environment so that he/she can keep carrying out his/her activities, in spite of being in a hospital environment.

It is important to highlight that new studies on this issue should be developed, providing the children who experience this situation with a voice, so that the child with cancer and his/her family can be properly cared for.

\section{REFERENCES}

1. Mansano-Schlosser TC, Ceolim MF. Qualidade de vida de pacientes com câncer no período de quimioterapia. Texto Contexto Enferm. 2012 Jul-Set; 21(3):600-7.

2. Instituto Nacional de Câncer (BR). Coordenação de Prevenção e Vigilância de Câncer. Câncer da criança e adolescente no Brasil: dados dos registros de base populacional e de mortalidade. Rio de Janeiro (RJ): INCA, 2008. 
3. Anders JC, Souza, AIJ. Crianças e adolescentes sobreviventes ao câncer: desafios e possibilidades. Ciênc Cuid Saúde. 2009 Jan-Mar; 8(1):131-7.

4. Silva JMM. O desenho na expressão de sentimentos em crianças hospitalizadas. Fractal: Revista de Psicologia, 2010 Mai-Ago; 22(2):447-56.

5. Lima LM, Bielemann VLM, Schuwartz E, Viegas AC, Santos BP, Lima JF. Adoecer de câncer: o agir e o sentir do grupo familiar. Ciênc Cuid Saúde. 2012 Jan-Mar; 11(1):106-12.

6. Sigaud CHS, Rezende MA, Veríssimo MDLOR, Ribeiro MO, Montes DC, Piccolo J, et al. Aspectos éticos e estratégias para a participação voluntária da criança em pesquisa. Rev Esc Enferm USP. 2009 Dez; 43(esp 2):342-6.

7. Vieira MA, Lima RAG. Crianças e adolescentes com doença crônica: convivendo com mudanças. In: Cruz SHV, organizador. A criança fala: a escuta de crianças em pesquisas. São Paulo (SP): Cortez; 2008. p. 372-5.

8. Polo LHV, Moraes MW. Performance de Zubrod e índice de Karnofsky na avaliação da qualidade de vida de crianças oncológicas. Einstein. 2009 Jul-Set; 7(3):314-21.

9. Aiello-Vaisberg TMJ. Ser e fazer. Enquadres diferenciados na clínica winnicottiana. Aparecida (SP): Ideias e Letras; 2004.

10. Trinca $W$. Investigação clínica da personalidade: o desenho livre como estímulo de apercepção temática. $3^{\text {a }}$ ed. São Paulo (SP): EPU; 2003.

11. Orlandi EP. Análise de discurso: princípios e procedimentos. $8^{\text {a }}$ ed. Campinas (SP): Pontes; 2009.

12. Cardoso FT. Câncer infantil: aspectos emocionais e atuação do psicólogo. Rev SBPH. 2007 Jun; 10(1):25-52.

13. Françoso LPC, Valle ERM. Assistência psicológica a crianças com câncer - os grupos de apoio. In: Valle ERM, organizador. Psico-oncologia pediátrica. $2^{\mathrm{a}} \mathrm{ed}$. São Paulo (SP): Casa do Psicólogo; 2011. p.75-127.
14. Barbosa LNF, Francisco AL. A subjetividade do câncer na cultura: implicações na clínica contemporânea. Rev SBPH, 2007 Jun; 10(1):9-24.

15. Forsait S, Castellanos MEP, Cordenonssi JT, Vicentini LL, Silva MMB, Miranda MC, et al. Impacto do diagnóstico e do tratamento de câncer e de aids no cotidiano e nas redes sociais de crianças e adolescentes. Arq Bras Ciên Saúde. 2009 Jan-Abr; 34(1):6-14.

16. Silva GM, Teles SS, Valle ERM. Estudo sobre as publicações brasileiras relacionadas a aspectos psicossociais do câncer infantil - período de 1998 a 2004. Rev Bras de Cancerol. 2005 Jul-Set; 51(3):25361.

17. Souza LPS, Silva RKP, Amaral RG, Souza AAM, Mota ÉC, Silva CSO. Câncer infantil: sentimentos manifestados por crianças em quimioterapia durante sessões de brinquedo terapêutico. Rev Rene. 2012 Jul-Set; 13(3):686-92.

18. Bueno PC, Neves ET, Rigon AG. O manejo da dor em crianças com câncer: contribuições para a enfermagem. Cogitare Enferm. 2011 Abr-Jun; 16(2):226-31.

19. Lopes DPLO, Valle ERM. A organização familiar e o acontecer do tratamento da criança com câncer. In: Valle ERM, organizador. Psico-oncologia pediátrica. $2^{\text {a }}$ ed. São Paulo (SP): Casa do Psicólogo; 2011. p.13-74.

20. Cavicchioli AC, Menossi MJ, Lima RAG. Câncer infantil: o itinerário diagnóstico. Rev Latino-am Enfermagem. 2007 Set-Out; 15(5):1025-32.

21. Mesquita DPC, Rosa FI. As heterogeneidades enunciativas como aporte teórico-metodológico para a análise do discurso de linha francesa. Rev Veredas. 2010 Jul-Dez; 14(2):130-41.

22. Ferreira MCL. O quadro atual da análise de discurso no Brasil. Rev Letras. 2003 Jul-Dez; 27(3):39-46. 